\title{
Effects of the Use of Ornamental Plants and Different Substrates in the Removal of Wastewater Pollutants through Microcosms of Constructed Wetlands
}

\author{
Luis Carlos Sandoval-Herazo ${ }^{1}$ (1), Alejandro Alvarado-Lassman ${ }^{1}$ (D) José Luis Marín-Muñiz ${ }^{2, *}$, \\ Juan Manuel Méndez-Contreras ${ }^{1}$ and Sergio Aurelio Zamora-Castro ${ }^{3}$ \\ 1 División de Estudios de Posgrados e Investigación, Tecnológico Nacional de México/Instituto Tecnológico \\ de Orizaba, Oriente 9, Emiliano Zapata Sur, C.P. 94320 Orizaba, Veracruz, México; \\ lcsandovalh@gmail.com (L.C.S.-H.); lassman@prodigy.net.mx (A.A.-L.); jmendezc@hotmail.com (J.M.M.-C.) \\ 2 El Colegio de Veracruz, Carrillo Puerto No. 26, 91000 Xalapa, Veracruz, México \\ 3 Facultad de Ingeniería, Universidad Veracruzana Bv. Adolfo Ruíz Cortines 455, Costa Verde, \\ C.P. 94294 Boca del Rio, Veracruz, México; sazc1976@hotmail.com \\ * Correspondence: soydrew@hotmail.com; Fax: 841-5100 (ext. 109)
}

Received: 11 April 2018; Accepted: 12 May 2018; Published: 16 May 2018

\begin{abstract}
The high costs involved in treating wastewater are problems that developing countries confront, mainly in rural areas. Therefore, Constructed Wetlands (CWs), which are composed of substrate, vegetation, and microorganisms, are an economically and ecologically viable option for wastewater treatment in these places. There is a wide variety of possibilities for substrates and ornamental plants that have not yet been evaluated to be implemented in future $\mathrm{CW}$ designs. The goal of this study was to evaluate the process of adaptation and removal of wastewater pollutants in CW microcosms using different terrestrial ornamental plants (Lavandula sp., Spathiphyllum wallisii, and Zantedeschia aethiopica). Those plants were sown in two types of substrate: red volcanic gravel (RVG) and polyethylene terephthalate (PET). CWs with vegetation reduced 5-day biochemical oxygen demand $\left(\mathrm{BOD}_{5}\right)$ by $68 \%$ with RVG substrate and $63 \%$ with PET substrate, nitrates $50 \%$ in RVG substrate and 35\% in PET substrate, phosphates 38\% in RVG substrate and 35\% in PET substrate, and fecal coliforms $64 \%$ in RVG and 59\% in PET substrate). In control microcosms without vegetation, reductions were significantly lower than those in the presence of plants, with reduction of $\mathrm{BOD}_{5}$ by $61 \%$ in RVG substrate and $55 \%$ in PET substrate, nitrates $26 \%$ in RVG substrate and $22 \%$ in PET substrate, phosphates $27 \%$ in RVG substrate and $25 \%$ in PET substrate. Concerning fecal coliforms $62 \%$ were removed in RVG substrate and 59\% in PET substrate. Regarding the production of flowers, Lavandula sp. did not manage to adapt and died 45 days after sowing and did not produce flowers. Spathiphyllum wallisii produced 12 flowers in RVG and nine flowers in PET, while Zantedeschia aethiopica produced 10 in RVG and 7 in PET. These results showed that the use of substrates made of RVG and PET is a viable alternative to be implemented in CWs. In addition, the reuse of PET is an option that decreases pollution by garbage. The plants Spathiphyllum wallisii and Zantedeschia aethiopica remarkably contribute in the removal of pollutants in wastewater. Additionally, the use of ornamental plants, with commercial interest such as those evaluated, enables an added value to the $\mathrm{CW}$ to be given, which can be used for flower production purposes on a larger scale and favor its acceptance within rural communities.
\end{abstract}

Keywords: wastewater treatment; ornamental plants; red volcanic gravel; PET 


\section{Introduction}

Water pollution is a problem all over the world [1]. The United Nations World Water Development Report estimates that $80 \%$ of wastewater (more than $95 \%$ in some developing countries) in the world is discharged without any previous treatment into the main rivers of Africa, Asia, and Latin America [2]. Therefore, the water quality is affected, the biodiversity of the species decreases and the concentrations of metals and other pollutants in the superficial aquatic systems increase [3], presenting a risk for the health of both humans [4] and the environment [5].

The conventional treatment systems to clean water, such as oxidation or stabilization lagoons, activated sludge, aeration, and upflow Anaerobic Sludge blanket, among others, require high costs in terms of construction, implementation and operation. Therefore, they are not suitable for using in communities where economic resources are scarce [6,7], like most of the rural areas in developing countries. Thus, it is important to investigate viable low cost alternatives to these populations. In this sense, constructed wetlands (CWs) are cost reduction alternatives for cleaning wastewater. CWs are ecotechnologies for the treatment of waters that imitate the functions of a natural wetland. These wetlands develop physical, chemical, and biological processes that allow the pollutants from wastewater to be removed without energy costs and with little maintenance. Consequently, they become an attractive option to solve problems of water contamination [8-11]. In the CW there are treatment interactions of the water with vegetation, the support medium (substrate) and the microorganisms that grow in the system [12]. The vegetation usually consists of typical macrophytes of natural wetlands, capable of surviving under flood conditions such as Typha latifolia, Phragmites australi,s and Cyperus papyrus [12-18]. However, a recent trend in CW is related to the use of flowering ornamental plants. These plants represent an option to treat the water and at the same time obtain a more aesthetic system. These species generally correspond to hydrophytes that may be typical of wetlands or terrestrial plants adapted to these conditions, such as Iris pseudacorus L. and Acorus gramineus. These hydrophytes have been used to treat industrial and rural wastewater [19]. Other species are Canna hybrids, which have been used in domestic waste water [20], Iris sibirica, used in waters produced by the pharmaceutical industry [21], Iris pseudacorus, Eichornia crassipes, Tulbaghia violacea, and Cyperus papyrus, used in domestic wastewater [22], as well as the genus Zingiberales, Heliconiasceae and cannaceae, used in raw wastewater [23]. Most of these studies are focused on the removal of pollutants, the growth and health of plants and, to a lesser extent, the production of flowers. On the other hand, there are gaps in the literature about the adaptation of terrestrial ornamental plants to survive in flood conditions and high nutrient loads [15]. According to Sandoval-Herazo et al., [7], using ornamental plants in CW, mainly in tropical areas, is a technique that may contribute to the generation of economic benefits, to improve the visual quality of the landscape and to foster communities to adopt this ecotechnology.

The support media or substrate for a future $\mathrm{CW}$ requires compliance with the characteristics that generate a good habitat for the development of biofilms of microorganisms that contribute to the removal process of pollutants [24-27]. Thus, they are made of porous and/or rough stone materials (volcanic rocks, gravels or sands) $[28,29]$. Besides, they should be easy to obtain in the areas where they are intended to be implemented, especially in tropical places [30], such as rural communities in Mexico, where there are problems of water pollution and lack of economically viable treatment plants. Nowadays, these materials have industrial applications that increase their commercial value. For this reason, it is important to evaluate new lower-cost and easy-to-obtain substrates [31], such as pieces of polyethylene terephthalate (PET).

PET is currently considered an environmental problem due to its long period of degradation, between 100 and 1000 years, and its abundant amount in the environment [32]. Therefore, applications where PET could be recycled would reduce its accumulation in landfills and other final disposal places.

The objective of this study was to evaluate the process of adaptation and removal of wastewater pollutants using terrestrial ornamental plants (Lavandula sp., Spathiphyllum wallisii, and Zantedeschia aethiopica) sown in two types of substrate (red volcanic gravel (RVG) and polyethylene terephthalate (PET)) by means of microcosms of constructed wetlands. 


\section{Materials and Methods}

\subsection{Characteristics of the CW System}

This study was carried out in Misantla, a village located in the mountainous central-northern area of the State of Veracruz, Mexico $\left(19^{\circ} 56^{\prime} \mathrm{N}\right.$ and $\left.96^{\circ} 51^{\prime} \mathrm{W}\right)$. The climate in the area is classified as warm and humid tropical, with rain falling all year, higher temperatures during the month of June and lower in the month of January, with an average annual temperature between $20-26{ }^{\circ} \mathrm{C}$. The altitude of the area is between 309 and $400 \mathrm{~m}$ above sea level, the average annual rainfall recorded is between 1900-2100 mm [33].

The microcosm-scale experiments were established in plastic cylinders $29 \mathrm{~cm}$ diameter and $36 \mathrm{~cm}$ height (experimental units). At $5 \mathrm{~cm}$ above the bottom of each cylinder, a hole of $3 / 8^{\prime \prime}$ diameter was made to insert an "S" shaped tube that ended at a height of $21 \mathrm{~cm}$ (Figure 1) simulating CW systems with a continuous vertical flow. A total of 16 experimental units were established. Eight units were filled with RVG, with the following characteristics: porous surface material of 0.79 , low hardness and low density [34], and $1.5 \mathrm{~cm}$ average diameter; collected from a material bank within the municipality of Misantla. The remaining eight were filled with PET as a substrate. This material was composed of rough and bent sections of recycled bottles that had been used to store water and soft drinks. In order to favor the development of bacterial communities, PET pieces were cut with diameters of 3 to $5 \mathrm{~cm}$. The experimental units were filled from the bottom to a height of $26 \mathrm{~cm}$ with the respective substrates used. In the case of the units filled with PET, a $10 \mathrm{~cm}$ layer of VGR was added at the level of water output to avoid PET flotation. This layer played no role in the experiment and prevented the development of vectors. The water supply in the microcosms of wetlands was calculated using the Hydraulic Flow Equation (FH) [12]:

$$
F H=\frac{\mathrm{V} * \mathrm{~d}}{T R H}
$$

where

$\mathrm{V}=$ Volume of the cell $(\mathrm{mL})$

$\mathrm{d}=$ porosity, or space available for the flow of water through the wetland (percentage expressed as decimal)

$\mathrm{TRH}=$ Hydraulic retention time (days)

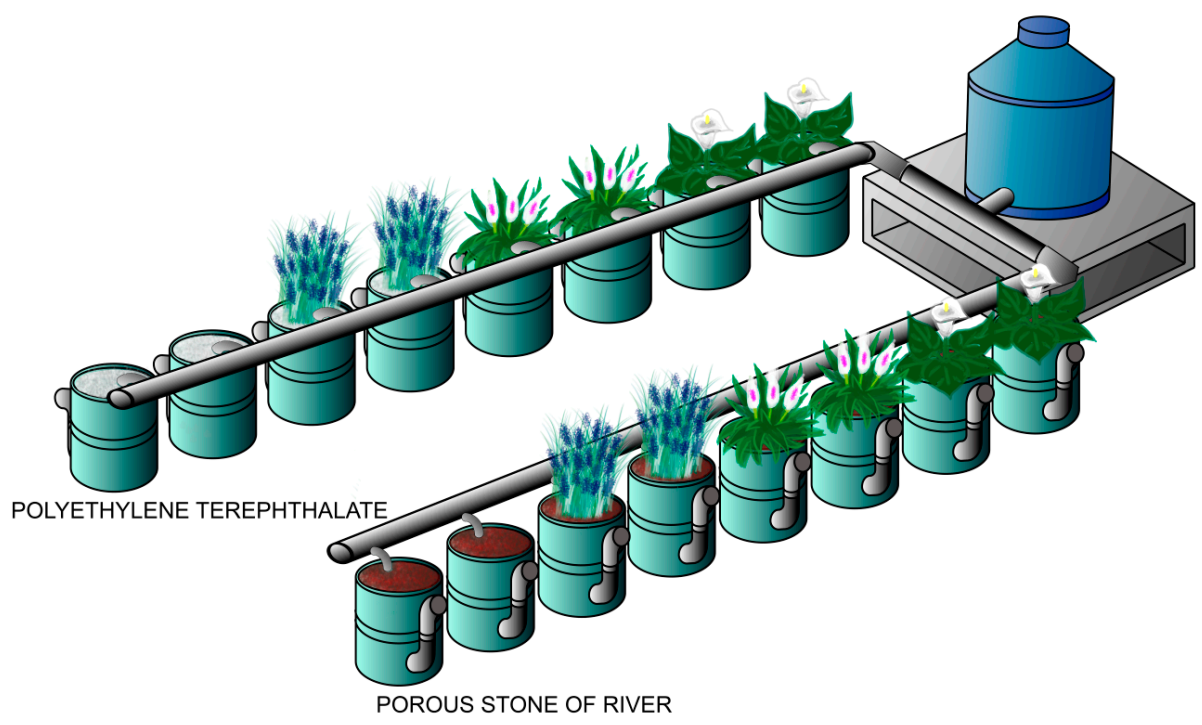

Figure 1. Microcosms of constructed wetlands (CWs) used in this study. 
The hydraulic retention time (HRT) value was 3 days in the 16 microcosms. Three different ornamental plant species were used: Lavandula sp., Spathiphyllum wallisii, and Zantedeschia aethiopica (12 to $19 \mathrm{~cm}$ height). 12 individuals were planted in duplicates according to the arrangement shown in Figure 1. The selection of the species considered that the plants were easy to adapt, and resistant to agents of weathering. Additionally, that they were of commercial interest and with the advantage of using systems as culture media [5,15,35-37]. The plants were acquired in two ways: Spathiphyllum wallisii and Zantedeschia aethiopica were collected from areas near the study site [38] and Lavandula sp. was acquired in a local nursery. The control units consisted of plastic cylinders filled with the substrates but without vegetation (Figure 1).

The first 30 days after planting vegetation, the CWs were fed with tap drinking water. Starting from day 31 of the study, and for 30 days thereafter, the water proportions were those indicated in Table 1. In order to adapt the vegetation to the new water quality conditions, starting from day 61, CWs were $100 \%$ fed with waste water that was stored in a $1500 \mathrm{~L}$ tank (fed every two days with an electric pump of $\frac{1}{2} \mathrm{HP}$ ). In the inner side of the tank an engine with propellers was installed to keep the residual water in constant movement, and to favor the removal of pollutants. The study was carried out at room temperature, under a polyethylene terephthalate shadow mesh, with a shade percentage of $35 \%$, for 300 days.

Table 1. Percentage of water that was fed constructed wetland (CW).

\begin{tabular}{ccc}
\hline Time (Days) & \% Residual Water & \% Tap Water \\
\hline 31 a 33 & 10 & 90 \\
34 a 39 & 20 & 80 \\
40 a 43 & 40 & 60 \\
44 a 47 & 60 & 40 \\
48 a 51 & 80 & 20 \\
52 a 60 & 90 & 10 \\
61 a 270 & 100 & 0 \\
\hline
\end{tabular}

\subsection{Experimental Design}

The CWs were evaluated with a two factor experimental design, factor one was plant species and factor two was substrate type.

\subsection{Sampling and Analysis}

From the day the tank was fed with $100 \%$ residual water and during the period from 30 June 2016 to 12 March 2017, every 15 days one sample was taken from the influent and the effluent of each CW. The samples were analyzed in the laboratory of water of the Instituto Tecnológico Superior de Misantla (ITSM). The biochemical oxygen demand $\left(\mathrm{BOD}_{5}\right)$, nitrates $\left(\mathrm{N}-\mathrm{NO}_{3}\right)$, phosphates $\left(\mathrm{P}^{-} \mathrm{PO}_{4}\right)$ and fecal coliforms (FC) were determined in duplicates by standard methods (APHA, AWWA, WEF, 2005). Total solids, electrical conductivity (EC), $\mathrm{pH}$, and water temperature were measured with a Hanna H198194 multiparameter meter, at the influent and the effluent of the microcosms. Besides these data, every 15 days, the environmental temperature and light intensity were measured with a 5PE71 hydrometer and HIELEC-MS8233-2000 luxometer, respectively, every 30 min between 9:00 to 10:00 and 14:00 to 15:00 $\mathrm{h}$. The average of each measurement was estimated and recorded. The height of the plant, measured with a measuring tape, and the number and size of the flowers were registered every 30 days.

\subsection{Statistical Analysis}

The response variables were the $\mathrm{BOD}_{5}$, nitrates, phosphates, and fecal coliforms, as well as plant height and number of flowers. Statistical differences among treatments were estimated by a two way ANOVA with species and substrates as factors, followed by less significant differences (LSD) tests, with a significance level of 5\%. All statistical analyzes were performed using the Minitab version 16.1.0 [39]. 


\section{Results and Discussion}

\subsection{Environmental Data}

The environmental temperature (Figure 2) ranged between $15{ }^{\circ} \mathrm{C}$ and $33^{\circ} \mathrm{C}$, the maximum temperature was registered during the month of July $\left(33^{\circ} \mathrm{C}\right)$. From August to November the average temperature was $23{ }^{\circ} \mathrm{C}$. These conditions are considered suitable for a good development of the plants, since they were consistent with those reported by Sacoto [40], who mentions that the optimal temperature ranges in subtropical climates for a good development of these species are between $12{ }^{\circ} \mathrm{C}$ to $25^{\circ} \mathrm{C}$. The average light intensity was $43,000 \pm 890$ lux (Figure 3), which indicates that it was in the optimal range (40,000 to 60,000 lux) for ornamental plants cultivation [41].

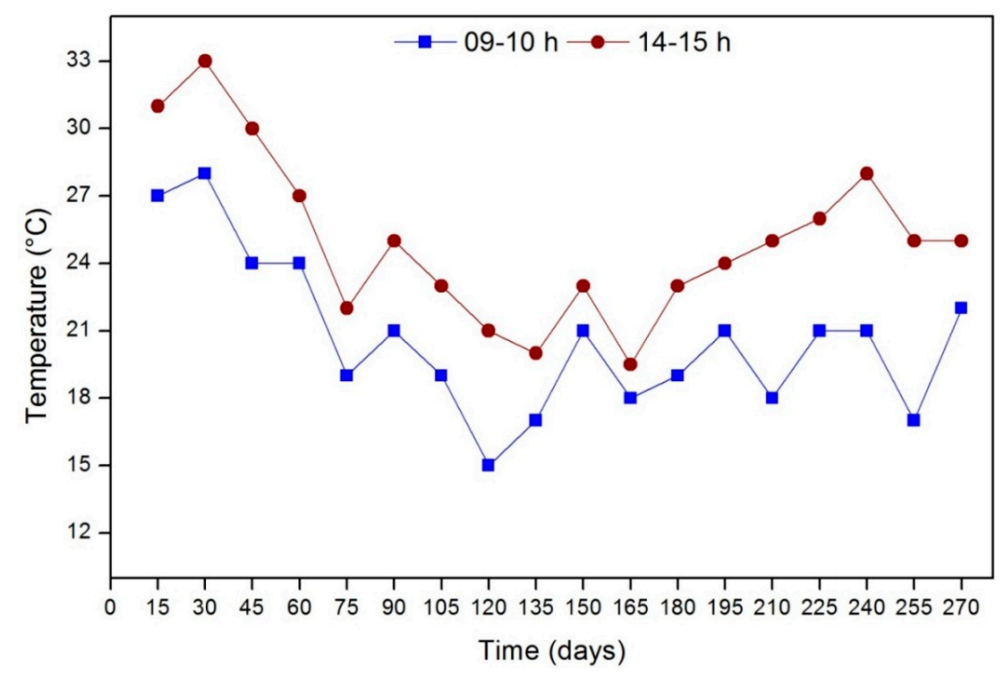

Figure 2. Environmental temperature registered between $9-10 \mathrm{~h}$ and $14-15 \mathrm{~h}$ of the day during the experiment period.

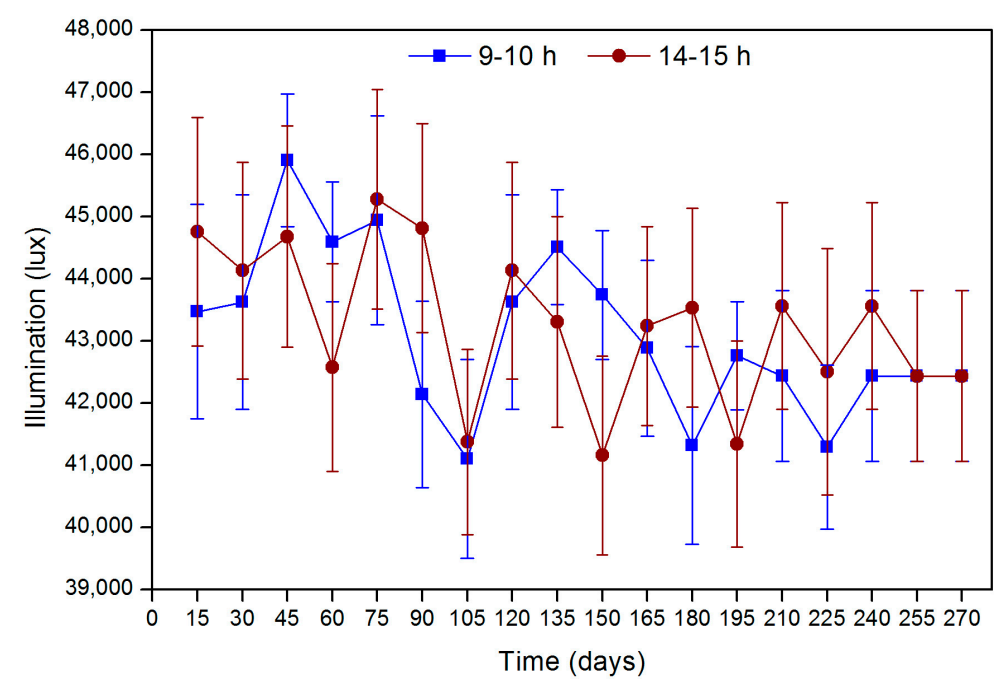

Figure 3. Light intensity registered between $9-10 \mathrm{~h}$ and $14-15 \mathrm{~h}$ of the day during the experimental period. Vertical bars represent the standard error of the mean.

\subsection{Plant Growth}

During the nine months of the study, the maximum recorded height of Zantedeschia aethiopica was $95 \mathrm{~cm}$ in the CWs with the RVG substratum; while with PET the maximum height was $81 \mathrm{~cm}$. 
These data were consistent with Morales et al. [42], who mention that this species reaches a maximum height of $1.5 \mathrm{~m}$ in its natural environment over a 12-month period. The height of Spathiphyllum wallisii was 31\% lower than Zantedeschia aethiopica in RVG and 19\% in PET (Figure 4).

Z. aethiopica and S. wallisii had similar growths in RVG and PET (Figure 4A,B), although PET is not a common substrate for any vegetation, while RVG is considered a more common substrate for CWs. The growth of the vegetation is a good indicator of plants adaptation to the system and their capacity to absorb nutrients. Lavandula sp., although considered adapted to different weather conditions, such as drought and frost, among others [43], was not able to survive in any of the substrates. The $\mathrm{pH}$ range of the effluents registered outside RVG and PET CWs in this experiment was between 7-7.4 (Figure 5). This range is found between the permissible limits for development of Lavandula sp., which are reported in ranges between 6.5 and 7.5 [44], while for Zantedeschia aethiopica values close to 7.0 are recommended [36], and for Spathiphyllum wallisii between 6.8 and 7.5 are considered suitable [45]. These data indicate that plants did not die due to these conditions. However, despite having an aerenchymous tissue with similar characteristics to those of wetland plants, Lavandula did not develop the same adaptability of its Lamiaceae family, capable of developing in areas with a constant presence of water, such as the Mentha pulegium [46].

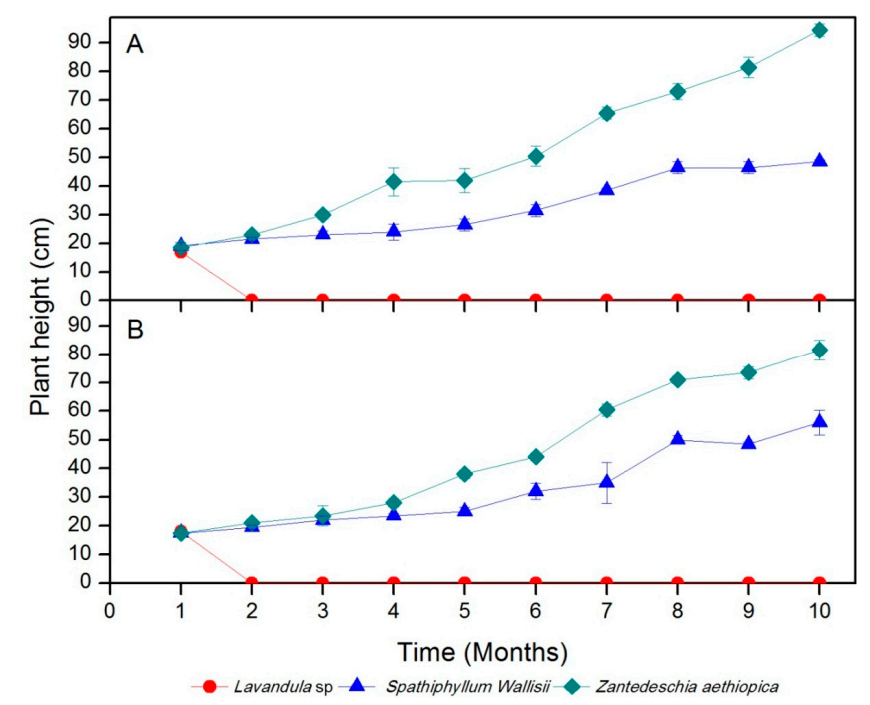

Figure 4. Plant height of Lavandula sp., Spathiphyllum wallisii, and Zantedeschia aethiopica registered in red volcanic gravel (RVG) (A) and polyethylene terephthalate (PET) (B) substrates.

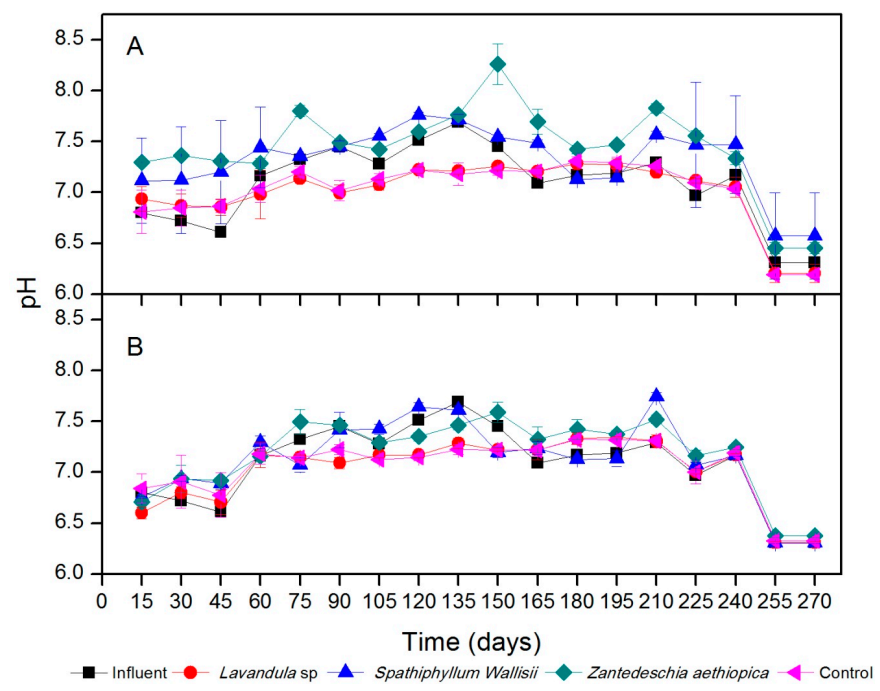

Figure 5. pH in influent and effluent in (A) RVG and (B) PET substrate. 


\subsection{Flower Production}

The production of flowers in Spathiphyllum wallisii in PET substrate was observed from the month of August. On average, these plants presented one flower per month during the flowering season (August to September 2016 and February to March 2017) (Table 2). In RVG there was a greater but irregular production of flowers, with a maximum of two flowers during the months of September, December, and March per experimental unit. Zantedeschia aethiopica produced flowers from July, getting its best production (two flowers per month) in the months of August, September, and October, and kept flowering during the rest of the experimental period. These results are according to the flowering period of these types of plants, which can be throughout the year. Besides, the light and temperature conditions presented during the experimental period were optimal as reported in similar studies for these species [37,47]. Regarding the quantity and size of the flowers (Table 2), the highest production was obtained in Spathiphyllum wallisii in the RVG substrate with 12 flowers in total during the entire study period. In PET substrate wallisii produced five flowers less than in RVG. On the other hand, the production of Zantedeschia aethiopica was 10 flowers for the RVG substrate and nine for PET substrate. Therefore, we consider that these species had a good adaptation to both substrates and environments.

The number of flowers was significantly different between CWs with PET and RVG $(p=0.0092)$, being higher in RVG, which means that the PET substrate reduced flower production in the three species. The interaction of the species sown in each type of substrate was not significant either $(p=0.051)$.

Table 2. Total production of flowers in microcosms. (Red volcanic gravel (RVG) and polyethylene terephthalate (PET.).

\begin{tabular}{cccc}
\hline Plants & Substrate & Number of Flowers & Flower Size (cm) \\
\hline Zantedeschia aethiopica & RVG & 10 & $36.4 \pm 11.4$ \\
Spathiphyllum wallisii & RVG & 12 & $11.2 \pm 3.3$ \\
Zantedeschia aethiopica & PET & 9 & $30.5 \pm 10.1$ \\
Spathiphyllum wallisii & PET & 7 & $9.2 \pm 4.1$ \\
\hline
\end{tabular}

3.3.1. $\mathrm{pH}$ in the Input and Output of the System

The appropriate $\mathrm{pH}$ range for the existence of most of life is 5 to 9 . In this regard, values that are under 5 and higher than 9 are complicated to treat by biological means [48]. In Figure 5A, the pH values obtained in both influent and effluent are shown. They ranged between 6.8 and 7.6 in RVG and between 6.6 and 7.8 in PET, being within typical values of domestic wastewater [49]. The decreases in the $\mathrm{pH}$ of some of the data (Figure 5B) are based on the removal of nitrogen that occurs in these systems, which causes a reduction in alkalinity [50]. $\mathrm{pH}$ values higher (8.1) than the values of the influent were found in microcosms planted with Zantedeschia aethiopica in RVG. This can be associated with photosynthesis of the plants, due to the consumption of $\mathrm{CO}_{2}$ during the day, which translates into an increase in $\mathrm{pH}$ in the system [51]. This occurred between 135 and 150 days of the study. The lowest values (6.3) of $\mathrm{pH}$ were found in PET, in the microcosms with Lavandula sp., between the 255 and 270 days of experiment. These values could be associated with the presence of organic matter from the roots of Lavandula sp. that could modify the chemical characteristics of the water in the microcosms or probably by oxidation of sulfur [52]. In general, values close to neutral were found during the 270 days of operation.

3.3.2. Temperature, Electrical Conductivity, and Total Dissolved Solids Concentrations in the Input and Output of the System

The water temperature (Table 3) directly affects the development of microorganisms [53]. The temperature of the influent was $23.34 \pm 0.70{ }^{\circ} \mathrm{C}$, while in microcosms with vegetation in RVG substrates it was between 16.75 and $17.54{ }^{\circ} \mathrm{C}$, and in the PET substrates between 16.78 and $17.63{ }^{\circ} \mathrm{C}$. These values are congruent with those reported by Akratos and Tsihrintzis [54], who indicate 
that the ideal temperature values for the removal of contaminants are between $16{ }^{\circ} \mathrm{C}$ and $32{ }^{\circ} \mathrm{C}$. Regarding total dissolved solids (TDS) in the wetland (Table 3), in the influent the average value found was $267.59 \pm 5.94 \mathrm{mg} \mathrm{L}^{-1}$. In the microcosm effluents with vegetation, regardless of the type of substrate, the values ranged from $138.71 \mathrm{mg} \mathrm{L}^{-1}$ to $178.82 \mathrm{mg} \mathrm{L}^{-1}$. In the microcosms without vegetation higher values were found than in the CWs with vegetation, with values ranging from $186.97 \mathrm{mg} \mathrm{L}^{-1}$ to $215.69 \mathrm{mg} \mathrm{L}^{-1}$. This measure can be altered by biological processes; however, the factors that most influence their values are the physical processes of dilution and evaporation [55]. In relation to the electrical conductivity (EC), it was observed that the value of the effluents decreased in relation to that of the influents, both in the microcosms with vegetation and in the microcosms without vegetation on average $240.75 \pm 28.37 \mu \mathrm{S} \mathrm{cm}^{-1}$. These results could be related to the absorption of ions, micro- and macro-elements in the roots and other tissues of the plants, in addition to the physical capacity to adsorb TDS of PET and RVG substrates [56].

\subsubsection{Concentrations of Pollutants}

$\mathrm{BOD}_{5}$ in the Input and Output of the System

In $\mathrm{CW}$, the elimination of $\mathrm{BOD}_{5}$ is presented by the interactions of several conditions such as absorption, sedimentation, and microbial metabolism [57]. Wetlands with vegetation favor bioremediation by releasing exudates, and enzymes that stimulate the development of microorganisms and biochemical activity in the rhizosphere [58]. In addition, in a wetland system with vegetation, the constant release of oxygen through the roots favors the reduction of $\mathrm{BOD}_{5}$. In this study, the average concentration of $\mathrm{BOD}_{5}$ in the influent was $115.96 \pm 23.1 \mathrm{mg} \mathrm{L}^{-1}$. The data from day 15 to 45 in systems with vegetation in RVG were $74.5 \pm 12.4 \mathrm{mg} \mathrm{L}^{-1}$ and in PET $77.4 \pm 13.5 \mathrm{mg} \mathrm{L}^{-1}$, while in the experimental units without vegetation with RVG were $94.5 \pm 0.5 \mathrm{mg} \mathrm{L}^{-1}$ and with PET $95.4 \pm 0.3 \mathrm{mg} \mathrm{L}^{-1}$ (Figure 6Aa,b). These values are relatively high in relation to those found by Marín-Muñiz [16], who reported $\mathrm{BOD}_{5}$ between 10 and $40 \mathrm{mg} \mathrm{L}^{-1}$ in CWs with vegetation, and 20 and $80 \mathrm{mg} \mathrm{L}^{-1}$ in units without vegetation. Therefore, we consider that our microcosms were new and a reasonable time is needed for the development of bacterial colonies that are fundamental in the removal process. This may explain the low removal results of $\mathrm{BOD}_{5}$ presented from day 15 to $45[59,60]$. From the samples taken from day 60 to 270 the concentrations oscillated between 10 and $50 \mathrm{mg} \mathrm{L}^{-1}$ in RVG and between 10 and $58 \mathrm{mg} \mathrm{L}^{-1}$ in PET (Figure 6Aa,b). In the influent, the concentrations of $\mathrm{BOD}_{5}$ registered were between 90 and $130 \mathrm{mg} \mathrm{L}^{-1}$. 
Table 3. Chemical parameters at input and output of wetland microcosms.

\begin{tabular}{|c|c|c|c|c|c|c|c|c|c|}
\hline \multicolumn{2}{|c|}{ Settings } & \multicolumn{8}{|c|}{ Wetland Plants in Different Substrates } \\
\hline Substrate & Influent & Lavandula sp. & $\begin{array}{l}\text { S. wallisii } \\
\text { PET }\end{array}$ & Z. aethiopica & Lavandula sp. & $\begin{array}{l}\text { S. wallisii } \\
\text { RVG }\end{array}$ & Z. aethiopica & $\begin{array}{c}\text { Control } \\
\text { RVG }\end{array}$ & $\begin{array}{c}\text { Control } \\
\text { PET }\end{array}$ \\
\hline Temperature $\left({ }^{\circ} \mathrm{C}\right)$ & $23.34 \pm 0.70$ & $17.18 \pm 0.19$ & $16.99 \pm 0.21$ & $17.44 \pm 0.19$ & $17.14 \pm 0.19$ & $16.94 \pm 0.19$ & $17.41 \pm 0.13$ & $17.61 \pm 0.16$ & $17.48 \pm 0.19$ \\
\hline $\mathrm{EC}\left(\mu \mathrm{S} \mathrm{cm}^{-1}\right)$ & $1306.45 \pm 52.07$ & $1116.98 \pm 36.01$ & $1167.94 \pm 28.75$ & $1118.48 \pm 29.22$ & $1012.89 \pm 32.86$ & $907.86 \pm 47.47$ & $997.13 \pm 28.75$ & $1050.2 \pm 43.51$ & $1146.22 \pm 39.48$ \\
\hline $\mathrm{SDT}\left(\mathrm{mg} \mathrm{L}^{-1}\right)$ & $267.59 \pm 5.94$ & $178.82 \pm 2.00$ & $183.71 \pm 1.67$ & $168.50 \pm 2.18$ & $156.25 \pm 2.70$ & $162.77 \pm 2.32$ & $138.60 \pm 1.96$ & $190.43 \pm 3.46$ & $212.99 \pm 2.70$ \\
\hline
\end{tabular}

Values are given as the average \pm standard error $(n=32)$; SDT (Total dissolved solids); EC (electrical conductivity); RVG (red volcanic gravel); PET (polyethylene terephthalate). 

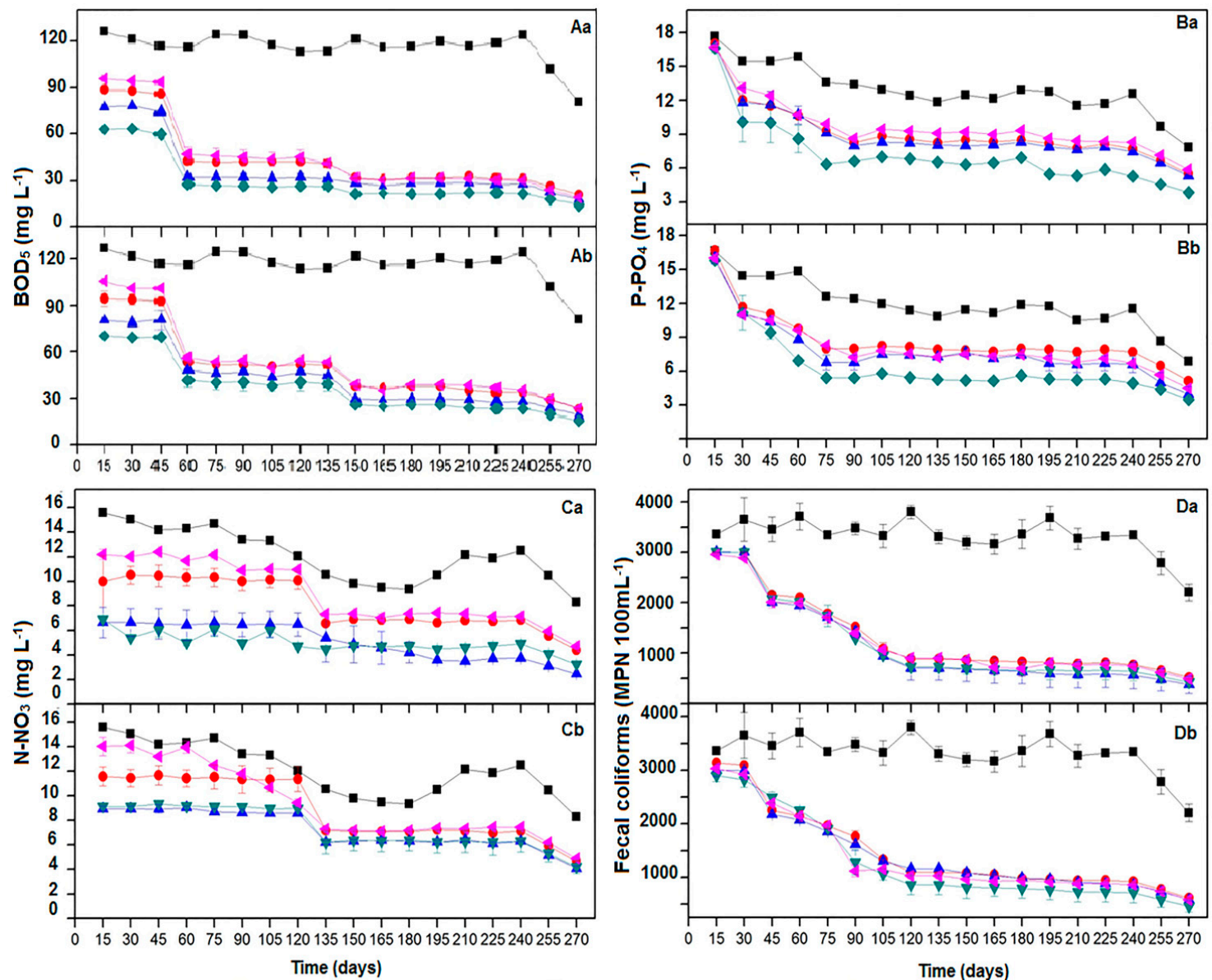

- Influent $\bullet$ Lavandula sp - - Spathiphyllum wallisii $\nabla$-Zandeteschia aethiopica 4 Control

Figure 6. Concentration of pollutants at the influent and effluent in (A) RVG and (B) PET substrates.

$\mathrm{P}-\mathrm{PO}_{4}$ in the Input and Output of the System

The influent concentrations of $\mathrm{P}_{-} \mathrm{PO}_{4}$ on average were $11.75 \pm$ 4.9. After the treatment, in both substrates, it was found that the systems with vegetation with RVG were $7.36 \pm 0.74 \mathrm{mg} \mathrm{L}^{-1}$ and $8.84 \pm 0.2 \mathrm{mg} \mathrm{L}^{-1}$ with PET (Figure 6Ba,b). Microcosms without vegetation had concentration averages between $8.63 \pm 2.49 \mathrm{mg} \mathrm{L}^{-1}$ and $11.40 \pm 2.42 \mathrm{mg} \mathrm{L}^{-1}$ in RVG and PET substrates, respectively (Figure 7). The decrease of nutrients in CWs with plants may be due to the absorption of nutrients [50,61-64], which is reflected in the growth of the vegetation.

$\mathrm{N}-\mathrm{NO}_{3}$ in the Input and Output of the System

The concentration of nitrogen in the influent was $11.95 \pm 3.65 \mathrm{mg} \mathrm{L}^{-1}$. It decreased in the microcosms with vegetation ranging from $5.82 \pm 1.64 \mathrm{mg} \mathrm{L}^{-1}$ to $8.10 \mathrm{mg} \mathrm{L}^{-1}$ for RVG, and $7.53 \pm 1.26 \mathrm{mg} \mathrm{L}^{-1}$ in PET (Figure $6 \mathrm{Ca}, \mathrm{b}$ ), while the systems without vegetation were $8.55 \pm 3.85 \mathrm{mg} \mathrm{L}^{-1}$ and $10.12 \pm 3.94 \mathrm{mg} \mathrm{L}^{-1}$ in RVG and PET, respectively. These data are justified by the role of plant roots, which release oxygen inside the CWs, also by the absorption of nutrients in their tissues as reported by Vymazal [63], which is exemplified by the vegetation growth, shown in Figure 4. The decrease in concentrations between 120 and 135 days was related to a period of rainfall that occurred in the area and which favored the dilution of the nutrient 

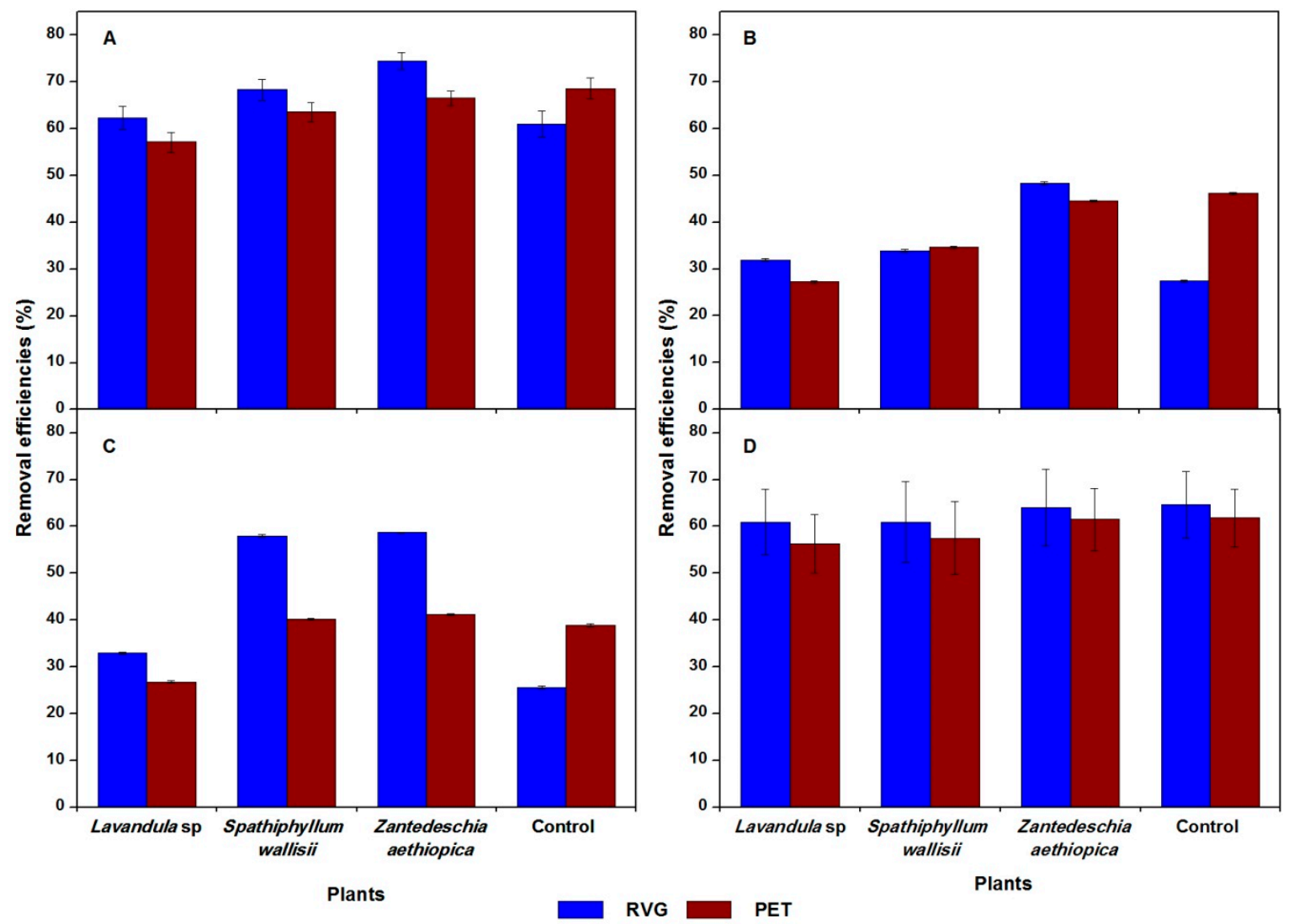

Figure 7. Reduction of $\mathrm{BOD}_{5}$ (5-day biochemical oxygen demand ) (A), $\mathrm{P}_{-} \mathrm{PO}_{4}$ (phosphates ) (B) and $\mathrm{N}-\mathrm{NO}_{3}$ (nitrates) (C) and $\mathrm{CF}$ (fecal coliforms) (D) in effluents and effluents of microcosms.

Fecal Coliforms in the Input and Output of the System

The concentrations of fecal coliforms in the wastewater were on average of $3319.31 \pm 64.4 \mathrm{NMP}$ (Most probable number) $100 \mathrm{~mL}^{-1}$. After passing through the systems with vegetation, this concentration dropped to average ranges in RVG of $1211.49 \pm 77.42 \mathrm{NMP} 100 \mathrm{~mL}^{-1}$, and in the CWs with vegetation in PET of $1386.97 \pm 54.01 \mathrm{NMP} \mathrm{mL}^{-1}$ (Figure $6 \mathrm{Da}, \mathrm{b}$ ).

\subsubsection{Removal of Pollutants}

\section{BOD}

The BOD reduction for the microcosms with vegetation in RVG substrates were between $62.32 \%$ and $74.46 \%$ and in PET between $57.11 \%$ and $68.59 \%$. For microcosms without vegetation, the removals were $60.99 \%$ and $54.89 \%$ in RVG and PET, respectively (Figure 7A), without statistical differences among substrates $(p=0.391)$. The difference between microcosms with and without vegetation was $7.8 \%$, which indicates that the removal took place more by microbial action and by adsorption in the substrates than by phytoremediation effects [16]. These results are congruent with those reported by Zurita et al. [36] using Z. aethiopica plants in tezontle substrate, where removals obtained oscillated between $78 \%$ and $83 \%$ in vertical flow wetlands. The values of water quality after treatment comply with the accepted parameters of the Environmental Protection Agency (Washington, DC, USA) reported by Veliz-Lorenzo et al. [61]. This means that this water may be used to irrigate trees, pastures for agricultural production, industrial crops, and parks, and other common uses for water treated by CWs [62]. Regarding the species, statistical differences were found in the BOD removals $(p=0.006)$. Besides this, significant differences between the two substrates with vegetation were found $(p<0.05)$; 
while in both substrates (RVG and PET) without vegetation, no statistical differences were observed in the removal of contaminants $(p=0.101)$.

\section{$\mathrm{P}-\mathrm{PO}_{4}$}

The reduction of $\mathrm{P}_{-} \mathrm{PO}_{4}$ (Figure 7B) that was found in the CWs with vegetation (S. wallisii and Z. aethiopica) was $34 \%$ and $48 \%$ in RVG substrate, and $35 \%$ and $45 \%$ in PET, respectively. This reduction was possibly due to processes of absorption by vegetation [63]. It has been reported that the absorption of phosphates by the action of plants is higher in tropical areas and that gravels have a low capacity for phosphate removal [65]. This information is congruent with the results presented in studies using tropical plants (Table 4). Concerning the CWs without plants, percentages of reduction obtained in substrates with RVG and PET were $27 \%$ and $25 \%$, respectively. The results obtained are consistent with those reported by Rousseaut et al. [66]. Although, different researches report that plant uptake is not a sustainable mechanism of elimination of $\mathrm{P}_{-} \mathrm{PO}_{4}$ [67], and that the main mechanism is the adsorption of this compound on substrates [68], our study shows that vegetation could play an important role in reduction of $\mathrm{P}_{-} \mathrm{PO}_{4}$ in tropical places. However, it is important to evaluate the combination of support media used in this study (RVG and PET) with others that have a greater capacity to remove $\mathrm{P}^{-} \mathrm{PO}_{4}$ [69], such as zeolite [70], and magnesium-containing materials [71].

Table 4. Comparison of CWs support media and their removal of contaminants.

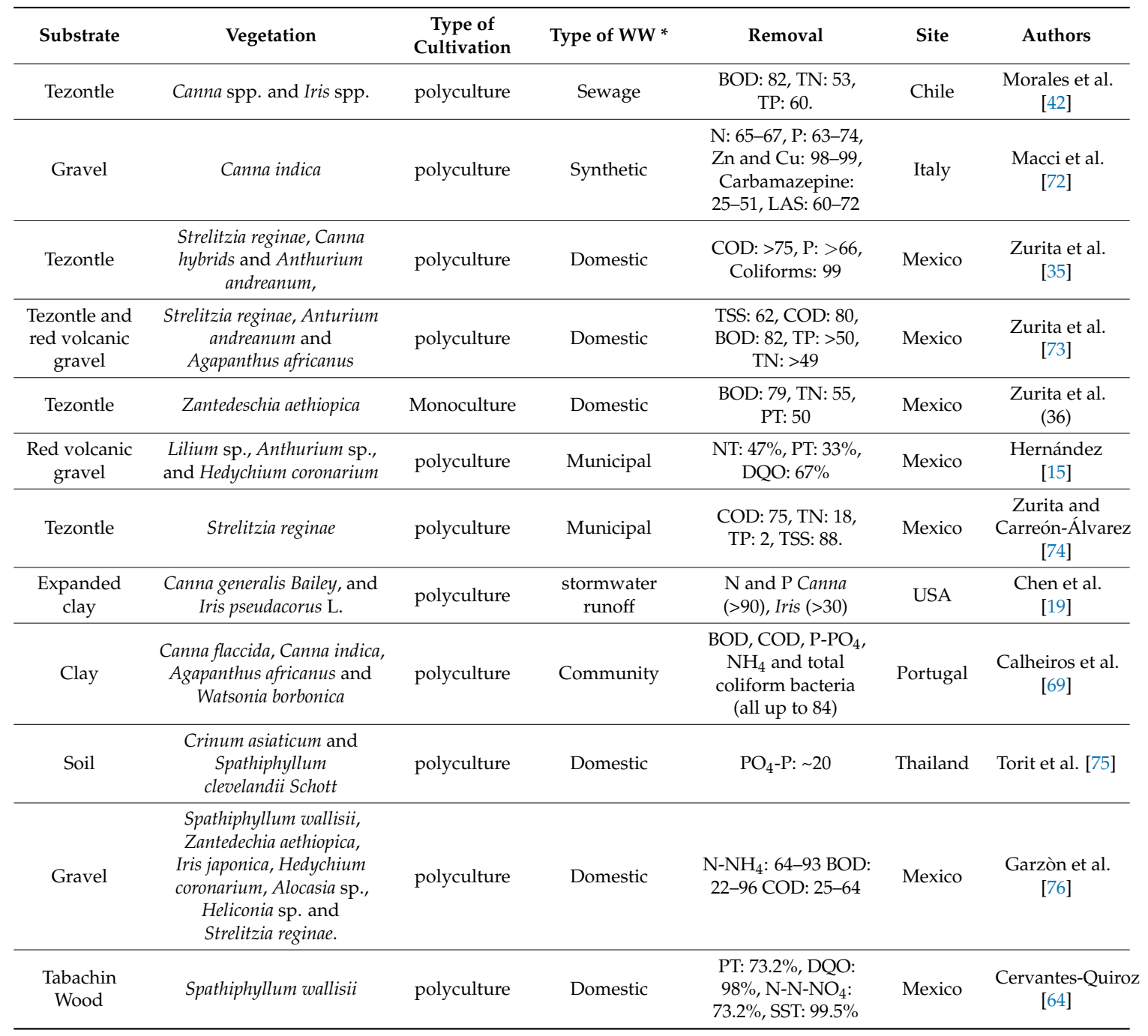

*WW: Wastewater. 
$\mathrm{N}-\mathrm{NO}_{3}$

Regarding the type of substrate, significant differences were observed between both substrates using vegetation $(p=0.001)$. The percentage of reductions obtained (Figure 7C) were greater in the microcosms with vegetation and RVG planted with S. wallisii and Z. aethiopica, where values of $58 \%$ and $59 \%$ were obtained, respectively. In the case of the CWs with PET and vegetation, the removals in the plants that survived were $40 \%$ with S. wallisii and $41 \%$ with Z. aethiopica, whereas in the microcosms without plants the values were $26 \%$ in RVG and $39 \%$ in PET. The main process involved in the removal of pollutants was on the substrates (adsorption). As it was observed in the growth, there was a process of phytoremediation (on average, $17 \%$ was favored by the presence of vegetation). Therefore, it is possible to justify that this could have been used for the development and growth of the plants, as previously described. Other processes as denitrification to eliminate nitrogen in $\mathrm{CW}$ were not investigated in this study $[77,78]$. The results obtained in this study are within the ranges of removal of contaminants found in other studies, such as those shown in Table 4. In these studies, substrates of stone origin were used [54,79], indicating that the substrates used in this study represent another option to use as filters in wetlands. Besides, the substrates used here are cheaper, easier to obtain, and solve other problems at the same time, such as the problem of saturation of garbage by PET.

There were not significant differences using RVG and PET without plants $(p=0.676)$. Although significant differences in $\mathrm{N}^{-\mathrm{NO}_{3}}$ were found between plant species. In RVG $(p=0.001)$ S. wallisii removed more nutrients than the other species $\left(4.99 \pm 2.21 \mathrm{mg} \mathrm{L}^{-1}\right)$. There is also a statistical significant difference using different plant species with PET $(p=0.011)$, S. wallisii being the one with the highest reduction, with an average of $7.23 \pm 2.41 \mathrm{mg} \mathrm{L}^{-1}$. Thus, it is clear that this species removes better in RVG substrate than in PET. The second species removing $\mathrm{N}-\mathrm{NO}_{3}$ was Z. aethiopica $\left(6.18 \pm 2.23 \mathrm{mg} \mathrm{L}^{-1}\right)$, and third in order was Lavandula sp. with $8.47 \pm 3.55 \mathrm{mg} \mathrm{L}^{-1}$. Although the plants died, the measurements of the concentrations of pollutants at the output of these experimental units continued throughout the experimental period, in case the remaining roots generated new outbreaks. However, the species did not support the conditions of wetlands.

\section{Fecal Coliforms}

The microcosms without vegetation in both substrates had no significant differences among them $(p=0.639)$. On average, reduction of coliforms was $65 \%$ in RVG and $62 \%$ in PET substrates (Figure 7D). These results are consistent with those obtained by Headley et al. [80], who did not find significant differences between the results of CWs vertical flow with vegetation and without vegetation. These results indicate that the vegetation does not play an important role in the elimination of CF (Fecal Coliforms). They are related to the fact that the CF cannot survive by intervals of time, directly influencing the time of hydraulic retention (THR) [81,82]. Therefore, it is recommended to evaluate the elimination of CF by increasing THR to favor more removals [65]. The release of antibiotics (such as phytometallophores and phytochelatins) by the roots of plants [83], plant cover, settlement of microorganisms, exposure to abiotic stress conditions such as $\mathrm{pH}$, temperature, and oxygen concentration can play important roles in the reduction of coliforms [84,85]. In addition, many of these factors are interrelated [86-88].

Consequently, no significant differences were observed in both substrates using vegetation $(p=0.873)$. There is not a significant difference, in the means of fecal coliforms, using different plants in RVG $(p=0.943)$. Although $S$. wallisii had better average mean removal of MPN (Most probable number) (1143.1 $\left.\mathrm{mg} \mathrm{L}^{-1}\right)$, there is not a statistically significant difference using different plant species with PET $(p=0.901)$. Even with this substrate, it was observed that CWs without vegetation presented a slightly higher average (8\%) than with Lavandula sp. and S. wallisii plants. However, with Z. aethiopica it was on average MPN $1267.1 \pm 814.23 \mathrm{mg} \mathrm{L}^{-1}$.

The use of PET as a substrate material is an innovation as a means of support and is an economically and ecologically viable alternative to treat wastewater in CWs. Its use in real-size wetlands would imply minimum investment costs in substrates, since PET can be obtained in the 
communities where these solutions are intended to be implemented. This way, it reduces the impact that this material causes to the environment due to its long period of biodegradation, and it would give a new use to this material, which is massively produced on the planet.

On the other hand, it is important to mention that in the literature there are few records on the use of ornamental plants, such as Spathiphyllum wallisii, and their adaptation and reduction of contaminants in CWs (Table 4). Yet, it is still important to evaluate polycultures in CWs at a mesocosm level to know the complete picture of the species and its biochemical interactions in these types of systems. Additionally, the use polycultures of ornamental plants that produce flowers in CWs would favor the acceptance of these systems in communities where it is necessary to implement them to solve problems of wastewater contamination. Regarding the Lavándula sp., the values obtained in both, concentration and removal, were similar to those observed in controls without vegetation and no significant differences were found $(p>0.05)$ because the plant died in both substrates (RVG and PET).

\section{Conclusions}

The main findings of this study reveal that PET waste as a means of support in CWs favored the removal of contaminants and the proper development of plants, being an innovation in use of this material as a substrate. The use of RVG showed favorable results with respect to the reduction of pollutants (nitrate, phosphates, biochemical oxygen demand, and fecal coliforms). The use of these substrates combined with others of stone origin could be considered in future studies in order to have a complete overview of their removal efficiency and for the development of plants, both at the microcosm and macrocosm levels, as well as in studies of different plant species that can be adapted to these systems using PET as a support medium. In the removal of pollutants, the ornamental plants S. wallisii and Z. aethiopica were able to adapt to the conditions of CWs and to use the pollutants for their growth. Therefore, the use of these ornamental plants in macrocosms and mesocosms of wetlands is recommended to treat wastewater in rural communities with problems of wastewater treatment. Additionally, the production of flowers indicates that these plants can become a source of economic income for the caretakers of wetlands and it may contribute to these ecotechnologies becoming accepted with greater landscape impact in societies where this type of solution is required. Lavandula sp. cannot adapt to wetland systems, so it is not recommended to use for CWs.

Author Contributions: A.A.-L., J.L.M.-M., J.M.M.-C. and S.A.Z.-C. conceived and designed the experiments; L.C.S.-H. performed the experiments; S.A.Z.-C. and J.M.M.-C. analyzed the data; S.A.Z.-C. contributed with reagents/materials/analysis tools; L.C.S.-H., A.A.-L., and J.L.M.-M. wrote the document.

Funding: This work was supported by the National Technological Institute of Mexico in the Call for Support for Scientific and Technological Research 2017 (469.17-PD).

Acknowledgments: The first author of the present study would like to thank the Instituto Tecnológico Superior de Misantla for allowing this project to be developed in its facilities. To the Civil Engineering undergraduate class of 2013 for its invaluable support in the collection of substrates and plants, the ones that were used for this purpose and Tecnológico de Orizaba for allowing him to pursue his PhD studies in the Engineering Sciences program belonging to PNPC-CONACYT, and finally CONACYT for the scholarship granted to pursue his doctoral studies.

Conflicts of Interest: The authors declare no conflict of interest.

\section{References}

1. Brueckner, M.; Schwandt, H. Income and population growth. Econ. J. 2015, 125, 1653-1676. [CrossRef]

2. Informe Mundial de las Naciones Unidas sobre el Desarrollo de los Recursos Hídricos Aguas residuales: El recurso desaprovechado. París, UNESCO. 2017. Available online: http:/ / unesdoc.unesco.org/images / 0024/002476/247647s.pdf (accessed on 1 March 2018).

3. Bielmyer-Fraser, G.K.; Waters, M.N.; Duckworth, C.G.; Patel, P.P.; Webster, B.C.; Blocker, A.; Crummey, C.H.; Duncan, A.N.; Nwokike, S.N.; Picariello, C.R.; et al. Assessment of metal contamination in the biota of four rivers experiencing varying degrees of human impact. Environ. Monit. Assess. 2017, 189. [CrossRef] [PubMed] 
4. Omar, Y.Y.; Parker, A.; Smith, J.A.; Pollard, S.J.T. Risk management for drinking water safety in low and middle income countries-cultural influences on water safety plan (WSP) implementation in urban water utilities. Sci. Total Environ. 2017, 576, 895-906. [CrossRef] [PubMed]

5. Ramírez-Carrillo, H.F.; Luna-Pabello, V.M.; Arredondo-Figueroa, J.L. Evaluación de un humedal artificial de flujo vertical intermitente, para obtener agua de buena calidad para la acuicultura. Rev. Mex. Ing. Quim. 2009, 8, 93-99.

6. Barbu, M.; Vilanova, R.; Meneses, M.; Santin, I. On the evaluation of the global impact of control strategies applied to wastewater treatment plants. J. Clean. Product. 2017, 149, 396-405. [CrossRef]

7. Sandoval-Herazo, L.; Marín-Muñiz, J.L.; Alvarado, A.; Castelán, R.; Ramírez, D. Diseño de un mesocosmo de humedal construidos con materiales alternativos para el tratamiento de aguas residuales en la comunidad de pastorías actopan, ver. In Congreso Interdisciplinario de Ingenierías; ITSM: Veracruz, Mexico, 2016; Available online: https:/ /www.researchgate.net/publication/318711824_Diseno_de_un_Mesocosmo_de_ Humedal_Construidos_con_Materiales_Alternativos_Para_el_Tratamiento_de_Aguas_Residuales_en_la_ Comunidad_de_Pastorias_Actopan_Ver (accessed on 16 March 2018).

8. Hernández, A.M.E. Ecological engineering for controlling water pollution in Latin America. Ecol. Dimens. Sustain. Soc. Econ. Dev. 2013, 64, 465-481. Available online: https://books.google.com.mx/books?hl=es\& lr=\&id=67ylBYamP7UC\&oi=fnd\&pg=PA465\&dq=8.\%09Hern\%C3\%A1ndez,+A,+M.E.+Ecological+ engineering+for+controlling+water+pollution+in+Latin+America.+Ecological+Dimensions+for+ Sustainable+Socio+Economic+Development.+2013.+465--481.+\&ots=StW2vQ6_Yx\&sig=V8HLjsDNCdHu2W-jaa2z46FTHE\#v=onepage\&q\&f=false (accessed on 16 March 2018).

9. Vymazal, J. The use of hybrid constructed wetlands for wastewater treatment with special attention to nitrogen removal: A review of a recent development. Water Res. 2013, 47, 4795-4811. [CrossRef] [PubMed]

10. Chen, Y.; Wen, Y.; Zhou, Q.; Vymazal, J. Effects of plant biomass on denitrifying genes in subsurface-flow constructed wetlands. Bioresour. Technol. 2014, 157, 341-345. [CrossRef] [PubMed]

11. Luo, B.; Ge, Y.; Han, W.; Fan, X.; Ren, Y.; Du, Y.; Chang, J. Decreases in ammonia volatilization in response to greater plant diversity in microcosms of constructed wetlands. Atmos. Environ. 2016, 142, 414-419. [CrossRef]

12. Mitsch, W.J.; Gosselink, J. Wetlands; John Wiley and Sons Inc.: New York, NY, USA, 2015.

13. Zhang, Z.; Rengel, Z.; Meney, K. Nutrient removal from simulated wastewater using Canna indica and Schoenoplectus validus in mono-and mixed-culture in wetland microcosms. Water Air Soil Pollut. 2017, 183, 95-105. [CrossRef]

14. Menon, R.; Holland, M.M. Phosphorus retention in constructed wetlands vegetated with Juncus effusus, Carex lurida, and Dichanthelium acuminatum var. acuminatum. Water Air Soil Pollut. 2013, 224. [CrossRef]

15. Hernández, M.E. Ornamental wetlands with community participation for the improvement of municipal water in Mexico. RINDERESU 2016, 1, 1-12.

16. Marín-Muñiz, J.L. Removal of wastewater pollutant in artificial wetlands implemented in Actopan, Veracruz, Mexico. Rev. Mex. Ing. Quím. 2016, 15, 553-563.

17. Rozema, E.R.; Gordon, R.J.; Zheng, Y. Harvesting plants in constructed wetlands to increase biomass production and $\mathrm{Na}^{+}$and $\mathrm{Cl}^{-}$removal from recycled greenhouse nutrient solution. Water Air Soil Pollut. 2016, 227. [CrossRef]

18. Li, W.; Zhong, J.; Yuan, G.; Fu, H.; Fan, H.; Ni, L.; Cao, T. Stoichiometric characteristics of four submersed macrophytes in three plateau lakes with contrasting trophic statuses. Ecol. Eng. 2017, 99, 265-270. [CrossRef]

19. Chen, Y.; Bracy, R.P.; Owings, A.D.; Merhaut, D.J. Nitrogen and phosphorous removal by ornamental and wetland plants in a greenhouse recirculation research system. HortScience 2009, 44, 1704-1711.

20. Merino-Solís, M.L.; Villegas, E.; de Anda, J.; López-López, A. The effect of the hydraulic retention time on the performance of an ecological wastewater treatment system: An anaerobic filter with a constructed wetland. Water 2015, 7, 1149-1163. [CrossRef]

21. Tejeda, A.; Torres-Bojorges, Á.X.; Zurita, F. Carbamazepine removal in three pilot-scale hybrid wetlands planted with ornamental species. Ecol. Eng. 2017, 98, 410-417. [CrossRef]

22. Burgos, V.; Araya, F.; Reyes-Contreras, C.; Vera, I.; Vidal, G. Performance of ornamental plants in mesocosm subsurface constructed wetlands under different organic sewage loading. Ecol. Eng. 2017, 99, 246-255. [CrossRef] 
23. Latune, R.L.; Laporte-Daube, O.; Fina, N.; Peyrat, S.; Pelus, L.; Molle, P. Which plants are needed for a French vertical-flow constructed wetland under a tropical climate? Water Sci. Technol. 2017, 75, 1873-1881. [CrossRef] [PubMed]

24. Chen, J.; Wei, X.D.; Liu, Y.S.; Ying, G.G.; Liu, S.S.; He, L.Y.; Yang, Y.Q. Removal of antibiotics and antibiotic resistance genes from domestic sewage by constructed wetlands: Optimization of wetland substrates and hydraulic loading. Sci. Total Environ. 2016, 565, 240-248. [CrossRef] [PubMed]

25. Long, Y.; Zhang, Z.; Pan, X.; Li, B.; Xie, S.; Guo, Q. Substrate influences on archaeal and bacterial assemblages in constructed wetland microcosms. Ecol. Eng. 2016, 94, 437-442. [CrossRef]

26. Hua, G.; Salo, M.W.; Schmit, C.G.; Hay, C.H. Nitrate and phosphate removal from agricultural subsurface drainage using laboratory woodchip bioreactors and recycled steel byproduct filters. Water Res. 2016, 102, 180-189. [CrossRef] [PubMed]

27. Cao, Q.; Wang, H.; Chen, X.; Wang, R.; Liu, J. Composition and distribution of microbial communities in natural river wetlands and corresponding constructed wetlands. Ecol. Eng. 2017, 98, 40-48. [CrossRef]

28. Maza-Márquez, P.; González-Martínez, A.; Rodelas, B.; González-López, J. Full-scale photobioreactor for biotreatment of olive washing water: Structure and diversity of the microalgae-bacteria consortium. Bioresour. Technol. 2017, 238, 389-398. [CrossRef] [PubMed]

29. Xue, H.; Zhou, P.; Huang, L.; Quan, X.; Yuan, J. Cathodic Cr (VI) reduction by electrochemically active bacteria sensed by fluorescent probe. Sens. Actuators B 2017, 243, 303-310. [CrossRef]

30. Toro-Vélez, A.; Madera-Parra, C.; Peña-Varón, M.; García-Hernández, H.; Lee, W.Y.; Walker, S.; Lens, P. Longitudinal removal of bisphenol-A and nonylphenols from pretreated domestic wastewater by tropical horizontal sub-surfaceconstructed wetlands. Appl. Sci. 2017, 7. [CrossRef]

31. Claveau-Mallet, D.; Wallace, S.; Comeau, Y. Model of phosphorus precipitation and crystal formation in electric arc furnace steel slag filters. Environ. Sci. Technol. 2012, 46, 1465-1470. [CrossRef] [PubMed]

32. Morillas, A.V.; Pérez, M.V.; Valdemar, R.M.E.; Contreras, M.M.; Islas, S.H.; Guillén, M.Y.L.O.; Filgueira, H.J.A. Generation, legislation and waste plastics in Latin America. Rev. Int. Contam. Ambient. 2017, 32, 63-76.

33. National Institute of Statistical Geography and Data Processing. Yearbook Statistical and Geographical of Veracruz de Ignacio de la Llave. 2014. Available online: http:/ / www.inegi.gob.mx (accessed on 1 March 2017).

34. Zurita, F.; Belmont, M.A.; De Anda, J.; White, J.R. Seeking a way to promote the use of constructed wetlands for domestic wastewater treatment in developing countries. Water Sci. Technol. 2011, 63, 654-659. [CrossRef] [PubMed]

35. Zurita, F.; De Anda, J.; Belmont, M.A. Performance of laboratory-scale wetlands planted with tropical ornamental plants to treat domestic wastewater. Water Qual. Res. J. Can. 2006, 41, 410-417.

36. Zurita, F.; Belmont, M.A.; De Anda, J.; Cervantes-Martinez, J. Stress detection by laser-induced fluorescence in Zantedeschia aethiopica planted in subsurface-flow treatment wetlands. Ecol. Eng. 2008, 33, 110-118. [CrossRef]

37. Zhang, X.B.; Liu, P.; Yang, Y.S.; Chen, W.R. Phytoremediation of urban wastewater by model wetlands with ornamental hydrophytes. J. Environ. Sci. 2007, 19, 902-909. [CrossRef]

38. Gómez-Pompa, A. Botanical Studies in the Region of Misantla, Veracruz (No. 200); Instituto Mexicano de Recursos Naturales Renovables: Misantla, VER, Mexico, 1996; Available online: https: / www.cabdirect.org/ cabdirect/abstract/19660605399 (accessed on 20 March 2018).

39. Minitab Inc. Software Minitab 16.1.0; Minitab Inc.: Pennsylvania, PA, USA, 2010.

40. Sacoto, G. Resulta ïtotécnia de Tres Variedades de Zantedeschia aethiopica L. Spreng, a la Aplicación de ácido Giberélico y Fertilización Orgánica, en el Quinche, Provincia de Pichincha. Tesis Ingeniería Agronómica, Universidad Estatal de Bolívar, Venezuela, 2010. Available online: http:/ /biblioteca.ueb.edu.ec/cgi-bin/ koha/opac-search.pl?q=su:\%22TRIGO\%22 (accessed on 10 March 2018).

41. Guzmán, A.B.M.; Palenius, H.G.N. Utilización De Un Sistema De Inmersión Temporal (Sit) Para Multiplicar Plantas Ornamentales De Agave Victoriae-Reginae (T. Moore). Jóvenes Cienc. 2017, 2, 1429-1433.

42. Morales, G.; López, D.; Vera, I.; Vidal, G. Humedales construidos con plantas ornamentales para el tratamiento de materia orgánica y nutrientes contenidos en aguas servidas. Theoria 2013, 22, 33-46.

43. López, X.; Bagisnky, C.; Portilla, G. Lavanda establecidas en la región central de chile1. Agric. Téc. 1997, $57,113-121$. 
44. Bermudez, M. Uso Industrial de Plantas Aromáticas Medicinales. Unpublished Ingeniería, Universidad Politécnica de Madrid, España, 2009. Available online: http:/ / ocw.upm.es/ingenieria-agroforestal/usoindustrial-de-plantas-aromaticas-y-medicinales. (accessed on 9 March 2018). (In Spanish)

45. Garzón-Zúñiga, M.A.; González-Zurita, J.; García-Barrios, R. Evaluación de un sistema de tratamiento doméstico para reúso de agua residual. Rev. Int. Contam. Ambient. 2016, 32, 199-211. [CrossRef]

46. Viejo-Montesinos, J.L. Biodiversidad, aproximación a la diversidad botánica y zoológica de España. In Memorias de la Real Sociedad Española de Historia Natural. Segunda época; Montesino, J.L.V., Ed.; Real Sociedad Española de Historia Natural: Barcelona, España, 2011.

47. Hernández, M.E.; Galindo-Zetina, M.; Carlos, H.H.J. Greenhouse gas emissions and pollutant removal in treatment wetlands with ornamental plants under subtropical conditions. Ecol. Eng. 2017. [CrossRef]

48. Ho, L.; Ho, G. Mitigating ammonia inhibition of thermophilic anaerobic treatment of digested piggery wastewater: use of $\mathrm{pH}$ reduction, zeolite, biomass and humic acid. Water Res. 2012, 46, 4339-4350. [CrossRef] [PubMed]

49. Fumasoli, A.; Buergmann, H.; Weissbrodt, D.G.; Wells, G.F.; Beck, K.; Mohn, J.; Udert, K.M. Growth of Nitrosococcus-related ammonia oxidizing bacteria coincides with extremely low $\mathrm{pH}$ values in high strength nitrogen wastewater. Environ. Sci. Technol. 2017. [CrossRef] [PubMed]

50. Casierra-Martínez, H.A.; Charris-Olmos, J.C.; Caselles-Osorio, A.; Parody-Muñoz, A.E. Organic matter and nutrients removal in tropical constructed wetlands using cyperus ligularis (cyperaceae) and echinocloa colona (poaceae). Water Air Soil Pollut. 2017, 228. [CrossRef]

51. Vinasco, J.P.S.; Solís, A.V. Estimación de gases de efecto invernadero en humedales construidos de flujo subsuperficial. Ing. Univ. 2011, 15, 519-533.

52. Rahman, K.Z.; Wiessner, A.; Kuschk, P.; Van-Afferden, M.; Mattusch, J.; Müller, R.A. Fate and distribution of arsenic in laboratory-scale subsurface horizontal-flow constructed wetlands treating an artificial wastewater. Ecol. Eng. 2011, 37, 1214-1224. [CrossRef]

53. Yalcuk, A.; Ugurlu, A. Comparison of horizontal and vertical constructed wetland systems for landfill leachate treatment. Bioresour. Technol. 2009, 100, 2521-2526. [CrossRef] [PubMed]

54. Akratos, C.S.; Tsihrintzis, V.A. Effect of temperature, HRT, vegetation and porous media on removal efficiency of pilot-scale horizontal subsurface flow constructed wetlands. Ecol. Eng. 2007, 29, 173-191. [CrossRef]

55. Tejeda, A.; López, Z.; Rojas, D.; Reyna, M.Z.; Barrera, A.; Zurita, F. Eficiencia de tres sistemas de humedales híbridos para la remoción de carbamazepina. Technol. Cienc. Agua 2015, 6, 19-31.

56. Kyambadde, J.; Kansiime, F.; Dalhammar, G. Nitrogen and phosphorus removal in substrate-free pilot constructed wetlands with horizontal surface flow in Uganda. Water Air Soil Pollut. 2005, 165, 37-59. [CrossRef]

57. Karathanasis, A.D.; Potter, C.L.; Coyne, M.S. Vegetation effects on fecal bacteria, BOD, and suspended solid removal in constructed wetlands treating domestic wastewater. Ecol. Eng. 2003, 20, 157-169. [CrossRef]

58. Chávez, P.; Fabiola, J.; Chimbo, Z.; Lucía, F. Estudio Comparativo de la Capacidad Depuradora de Phragmites Australis y Cyperus Papyrus en Humedales Artificiales Subsuperciales de Flujo Vertical Para el Tratamiento de Aguas Residuales en el Cantón Santa Isabel. Bachelor's Thesis, Universidad de Cuenca, San Joaquin County, CA, USA, December 2015.

59. Olguín, E.J.; Sánchez-Galván, G.; González-Portela, R.E.; López-Vela, M. Constructed wetland mesocosms for the treatment of diluted sugarcane molasses stillage from ethanol production using Pontederia sagittata. Water Res. 2008, 42, 3659-3666. [CrossRef] [PubMed]

60. Hayder, G.; Ahmed, A.N.; Fu'ad, N.F.S.M. A review on media clogging in attached growth system. Int. J. Appl. Eng. Res. 2017, 12, 8034-8039.

61. Veliz-Lorenzo, E.; Llanes Ocaña, J.G.; Asela Fernández, L.; Bataller Venta, M. Reúso de aguas residuales domésticas para riego agrícola. Valoración crítica. Rev. CENIC. Cienc. Biol. 2009, 40, 35-44.

62. Marín-Muñiz, J.L.; García-González, M.C.; Ruelas-Monjardín, L.C.; Moreno-Casasola, P. Influence of different porous media and ornamental vegetation on wastewater pollutant removal in vertical subsurface flow wetland microcosms. Environ. Eng. Sci. 2018, 35, 88-94. [CrossRef]

63. Vymazal, J. Constructed wetlands for wastewater treatment. Water 2010, 2, 530-549. [CrossRef]

64. Stottmeister, U.; Wießner, A.; Kuschk, P.; Kappelmeyer, U.; Kästner, M.; Bederski, O.; Moormann, H. Effects of plants and microorganisms in constructed wetlands for wastewater treatment. Biotechnol. Adv. 2003, 22, 93-117. [CrossRef] [PubMed] 
65. García, M.; Soto, F.; González, J.M.; Bécares, E. A comparison of bacterial removal efficiencies in constructed wetlands and algae-based systems. Ecol. Eng. 2009, 32, 238-243. [CrossRef]

66. Rousseau, D.P.; Vanrolleghem, P.A.; De Pauw, N. Model-based design of horizontal subsurface flow constructed treatment wetlands: A review. Water Res. 2004, 38, 1484-1493. [CrossRef] [PubMed]

67. Gill, L.W.; O’Luanaigh, N.; Johnston, P.M. On-site wastewater treatment using subsurface flow constructed wetlands in Ireland. J. Environ. Sci. Health Part A 2011, 46, 723-728. [CrossRef] [PubMed]

68. Ghosh, D.; Gopal, B. Effect of hydraulic retention time on the treatment of secondary effluent in a subsurface flow constructed wetland. Ecol. Eng. 2010, 36, 1044-1051. [CrossRef]

69. Calheiros, C.S.; Bessa, V.S.; Mesquita, R.B.; Brix, H.; Rangel, A.O.; Castro, P.M. Constructed wetland with a polyculture of ornamental plants for wastewater treatment at a rural tourism facility. Ecol. Eng. 2015, 79, 1-7. [CrossRef]

70. Huang, J.H.; Paul, S.; Mayer, S.; Moradpour, E.; Hasselbach, R.; Gieré, R.; Alewell, C. Metal biogeochemistry in constructed wetlands based on fluviatile sand and zeolite-and clinopyroxene-dominated lava sand. Sci. Rep. 2017, 7. [CrossRef] [PubMed]

71. Lan, W.; Zhang, J.; Hu, Z.; Ji, M.; Zhang, X.; Zhang, J.; Yao, G. Phosphorus removal enhancement of magnesium modified constructed wetland microcosm and its mechanism study. Chem. Eng. J. 2018, 335, 209-214. [CrossRef]

72. Macci, C.; Peruzzi, E.; Doni, S.; Iannelli, R.; Masciandaro, G. Ornamental plants for micropollutant removal in wetland systems. Environ. Sci. Pollut. Res. 2015, 22, 2406-2415. [CrossRef] [PubMed]

73. Zurita, F.; De Anda, J.; Belmont, M.A. Treatment of domestic wastewater and production of commercial flowers in vertical and horizontal subsurface-flow constructed wetlands. Ecol. Eng. 2009, 35, 861-869. [CrossRef]

74. Zurita, F.; Carreón-Álvarez, A. Performance of three pilot-scale hybrid constructed wetlands for total coliforms and Escherichia coli removal from primary effluent-a 2-year study in a subtropical climate. J. Water Health 2015, 13, 446-458. [CrossRef] [PubMed]

75. Torit, J.; Siangdung, W.; Thiravetyan, P. Phosphorus removal from domestic wastewater by Echinodorus cordifolius L. J. Environ. Sci. Health Part A 2012, 47, 794-800. [CrossRef] [PubMed]

76. Garzón-Zúñiga, M.A.; Tomasini-Ortíz, A.C.; Moeller-Chavez, G.; Hornelas-Uribe, Y.; Buelna, G.Y.; Mijaylova-Nacheva, P. Enhanced pathogen removal in on-site biofiltration systems over organic filtration materials. What Pract. Technol. 2008, 3, 1-8.

77. Kadlec, R.H. Comparison of free water and horizontal subsurface treatment wetlands. Ecol. Eng. 2009, 35-2, 159-174. [CrossRef]

78. He, Y.; Peng, L.; Hua, Y.; Zhao, J.; Xiao, N. Treatment for domestic wastewater from university dorms using a hybrid constructed wetland at pilot scale. Environ. Sci. Pollut. Res. 2018. [CrossRef] [PubMed]

79. Garcia, J.; Rousseau, D.P.; Morato, J.; Lesage, E.L.S.; Matamoros, V.; Bayona, J.M. Contaminant removal processes in subsurface-flow constructed wetlands: A review. Crit. Rev. Environ. Sci. Technol. 2010, 40, 561-661. [CrossRef]

80. Headley, T.; Nivala, J.; Kassa, K.; Olsson, L.; Wallace, S.; Brix, H.; Müller, R. Escherichia coli removal and internal dynamics in subsurface flow ecotechnologies: Effects of design and plants. Ecol. Eng. 2013, 61, 564-574. [CrossRef]

81. Avelar, F.F.; De Matos, A.T.; De Matos, M.P.; Borges, A.C. Coliform bacteria removal from sewage in constructed wetlands planted with Mentha aquatica. Environ. Technol. 2014, 35, 2095-2103. [CrossRef] [PubMed]

82. Wu, H.; Lin, L.; Zhang, J.; Guo, W.; Liang, S.; Liu, H. Purification ability and carbon dioxide flux from surface flow constructed wetlands treating sewage treatment plant effluent. Bioresour. Technol. 2016, 219, 768-772. [CrossRef] [PubMed]

83. Vymazal, J. Plants used in constructed wetlands with horizontal subsurface flow: A review. Hydrobiologia 2011, 674, 133-156. [CrossRef]

84. Weerakoon, G.M.P.R.; Jinadasa, K.B.S.N.; Herath, G.B.B.; Mowjood, M.I.M.; Zhang, D.; Tan, S.K.; Jern, N.W. Performance of tropical vertical subsurface flow constructed wetlands at different hydraulic loading rates. Clean. Soil Air Water 2016, 44, 938-948. [CrossRef]

85. Hinds, T.D., Jr.; Brown, R.R.; Burns, E.H., Jr. Reduction of Fecal Coliform Levels in Two Created Wetlands at the Olentangy River Wetland Research Park; Springer: Portsmouth, OH, USA, 2004. 
86. Smith, E.; Gordon, R.; Madani, A.; Stratton, G. Pathogen removal by agricultural constructed wetlands in cold climates. J. Environ. Inf. 2005, 6, 46-50. [CrossRef]

87. Mesquita, C.; Albuquerque, A.; Amaral, L.; Nogueira, R. Effectiveness and temporal variation of a full-scale horizontal constructed wetland in reducing nitrogen and phosphorus from domestic wastewater. Chem. Eng. 2008, 2. [CrossRef]

88. Marín-Muñiz, J.L. Humedales. In Riñones del Planeta y Hábitat de Múltiples Especies; de Veracruz, E.C., Ed.; Editora de Gobierno del Estado de Veracruz: Veracruz, Mexico, 2018.

(c) (c) 2018 by the authors. Licensee MDPI, Basel, Switzerland. This article is an open access article distributed under the terms and conditions of the Creative Commons Attribution (CC BY) license (http:/ / creativecommons.org/licenses/by/4.0/). 